\title{
WHAT DOES THE UNITING FOR PEACE RESOLUTION MEAN FOR THE ROLE OF THE UN SECURITY COUNCIL?
}

\author{
Ieva Miluna*
}

The Uniting for Peace ${ }^{1}$ resolution together with the UN Charter prescribes a certain role for the General Assembly with regard to international peace and security. Larry Johnson addresses ${ }^{2}$ that role, but he does not consider a second question: how does the Uniting for Peace resolution affect the UN Security Council? The normative role of the Council is influenced not only by the Charter, but also by general international law. In this comment, I explore the normative role of the Council in fulfilling the Charter's purpose to maintain international peace and security. I argue that the text of the Charter and the prior practice of both the Assembly and the Council help to determine the proper division of these organs' respective tasks within the Charter system. I conclude that the Council alone exercises the constant control needed to enforce measures of collective security effectively, and that the Assembly is limited to recommending the consequences for states when threats or breaches of the peace occur.

The operational role of the Council is stipulated in the Charter and is shaped by Article $39,{ }^{3}$ which specifically states that this political organ is responsible for determining the existence of a threat to the peace, breach of the peace, or act of aggression. The Council is authorized to make recommendations or take decisions to maintain or restore peace and security in response to such determinations. The critical wording here is "to maintain or restore peace and security." The Council is given broad license to respond to all challenges to international peace and security. It also exercises constant authority while discharging these duties. Article $28^{4}$ of the Charter prescribes that the Council should be organized so as to function continuously, that members of the Council accordingly have a duty to be present at all times, and that to this end the Council shall hold periodic meetings at the UN seat or elsewhere. While Johnson notes that the Assembly can be available on a continuous basis, it is only the Council that is anticipated to do so and that is under an obligation to be in the position to constantly address threats to the peace and follow up on them. To this end, the Council has established sanctions, counter-terrorism, non-proliferation, and other standing committees as subsidiary organs (Article 295). These exist on a permanent basis until terminated at the Council's discretion.

The Council's binding resolutions under Chapter VII are enforcement action. Johnson thoroughly discusses the extent to which the use of force can be enforced by measures of the Assembly. But what are the

\footnotetext{
* Ph.D. candidate at the University of Amsterdam and Visiting Research Scholar at Fordham Law School. Originally published online 17 July 2014.

${ }^{1}$ Uniting for Peace, GA Res. 377A(V) (Nov. 3, 1950).

2 Larry D. Johnson, "Uniting for Peace": Does it Still Serve Any Useful Purpose?, 108 AJIL Unbound 106 (2014).

${ }^{3}$ UN Charter art. 39.

${ }^{4}$ UN Charter art. 28.

${ }^{5}$ UN Charter art. 29.
} 
residual functions of the Assembly that remain within its competence due to its secondary role in the maintenance of international peace and security under Article $11(2)^{6}$ of the Charter?

While the primary tasks of the Assembly are to consider general principles of cooperation in maintaining peace and security (Article 11(1) $)^{7}$, its practice demonstrates its engagement with specific situations (Korea, the Suez Crisis, the Middle East, Congo, South Africa, and others). While Article 18(2) ${ }^{8}$ of the Charter contemplates the kinds of "decisions" that can be taken by the Assembly, including recommendations with regard to the maintenance of international peace and security, the substance of these determinations varies on the basis of Articles 11(1), 11(2), or 14. ${ }^{9}$ Moreover, the last sentence in Article 11(2) stipulates that any question where action is necessary needs to be referred to the Council.

Articles 11(1) and 11(2) differentiate between: 1) recommendations with regard to general principles of cooperation in the maintenance of international peace and security, and 2) recommendations on any questions relating to the maintenance of international peace and security. The latter anticipates Assembly recommendations on particular situations. Article 14 addresses the possibility of Assembly measures directed at the peaceful adjustment of a situation. However, in the leading opinion on point, the ICJ did not elaborate on the scope of measures that can be recommended under Article 14. In its Certain Expenses of the United Nations ${ }^{10}$ opinion dealing with the UNEF mission in the Middle East, the Court merely indicated that these imply some kind of action involving "the maintenance of international peace and security." In the case of Namibia, where the Assembly terminated the mandate of South Africa, the ICJ affirmed that the Assembly, although vested with recommendatory powers, is entitled to adopt resolutions which make determinations or have operative design. However, even when making these specific determinations relating to enforcement, the Assembly is still accompanied by the Council. The Advisory Opinion in the Namibia case assumed that the Assembly lacked the necessary powers to ensure the withdrawal of South Africa from Namibia and needed the Council to ensure that this would occur. For this reason, Assembly Resolution 2145 (XXI) ${ }^{11}$ enlisted the cooperation of the Council, acting in accordance with Article 11(2) of the Charter. Similarly, in the Certain Expenses Advisory Opinion, where the Council authorized the Secretary-General to take the necessary steps to provide the Government of Congo with military assistance that as such did not involve "preventive or enforcement measures," it required the Secretary-General "to report to the Security Council as appropriate," thus affirming the Council's constant authority over the issue.

The case of South Africa also demonstrates that the Council exercises constant authority over cases involving international peace and security. In its Resolution 269 (1969), 12 the Council called upon South Africa to withdraw its administration from Namibia immediately. Later on, the Council exercised control over the situation by stating in its Resolution $276(1970)^{13}$ that the continued presence of South Africa in Namibia was illegal. Similarly, in the case of Congo, despite the fact that the underlying UN operation did not entail "preventive or enforcement measures," the ICJ still referred to the fact that the Council resolution of July 14, 1960 was clearly adopted with a view to maintaining international peace and security, and that the Assembly's involvement did not usurp or impinge upon the prerogatives conferred on the Council by the Charter.

${ }^{6} \underline{\mathrm{UN}}$ Charter art. 11, para. 2.

${ }^{7}$ UN Charter art. 11, para. 1.

${ }^{8}$ UN Charter art. 18, para. 2.

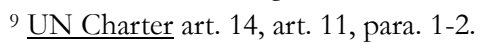

${ }^{10}$ Certain Expenses of the United Nations (Article 17, Paragraph 2, of the Charter), Advisory Opinion, 1962 ICJ REP. 151, 166 (July 20).

${ }^{11}$ GA Res. 2145 (XXI) (Oct. 27, 1966).

12 SC Res. 269 (Aug. 12, 1969).

${ }^{13} \underline{\text { SC Res. } 276}$ (Jan. 30, 1970). 
Although one of the Purposes of the United Nations is to maintain international peace and security and the Charter contemplates that the Assembly plays a role in that function, Article 1(1) 14 of the Charter goes on to make clear that when it comes to taking effective collective measures for the prevention and removal of a threat to the peace or for the suppression of acts of aggression or other breaches of the peace, these actions are for the Council. It is up to the Council under Article 24(1) ${ }^{15}$ and Chapters VI ${ }^{16}$ and VII ${ }^{17}$ to take effective (collective) measures, and it is in continuous session precisely to be in the position to constantly monitor ongoing threats to international peace and security. The Uniting for Peace resolution itself acknowledges "the importance of the exercise by the Security Council of its primary responsibility for the maintenance of international peace and security." This language acknowledges that the Council is the political organ entrusted with the task of taking effective collective measures.

The two prior conditions for invoking the Uniting for Peace resolution-namely, that a permanent member of the Council has used a veto and that the situation is a threat to the peace, breach of the peace, or act of aggression-were affirmed by the ICJ in the "Wall" case. ${ }^{18}$ This rather procedural matter raises the question of whether the veto could be used in cases of violations of international law obligations, which the UN organs have assumed and which at the same time are the obligations of the UN Member States individually. For example, in the High-level Panel Report on Threats, Challenges, and Change ${ }^{19}$ and elsewhere, ${ }^{20}$ permanent members of the Council have been encouraged to refrain from using the veto in cases of genocide and large-scale human rights abuses. This means that the Council is still considered a treasurer of international law obligations, and, as such, can embody a potential obstacle to the fulfillment of criterion for the use of veto by a permanent member.

Further, in cases when the Assembly has been involved in addressing the issues of international peace and security due to the use of veto by a permanent member at the Council, its practice shows that it has made determinations only with regard to the consequences of the breach of the peace or the act of aggression. It has not actively engaged in recommending the effective collective measures to which the Uniting for Peace resolution refers, except in the situations of Korea and Congo. In several cases it has referred to prior Council action, thereby acknowledging the Council's primary role in the maintenance of international peace and security.

Examining the Assembly's practice, in the situation of Korea ${ }^{21}$ in 1951 it determined that the Central People's Government of the People's Republic of China had engaged aggression in Korea and called for it to cease hostilities, at the same time affirming the existing Council's prescribed military assistance to the Republic of Korea. In 1956, in the case of the Suez Crisis, ${ }^{22}$ the Assembly established the UN Command for an emergency international Force to secure and supervise the cessation of hostilities that had arisen due to the Israeli, French, and British attack on Egypt, thereby addressing the consequences of the underlying breach of the peace. In the same year, after the Soviet invasion of Hungary, the Assembly called upon ${ }^{23}$ the Soviet

14 UN Charter art. 1, para. 1.

${ }^{15}$ UN Charter art. 24, para. 1.

${ }^{16}$ UN Charter arts. 33-38.

${ }^{17}$ UN Charter arts. 39-51.

${ }^{18}$ Legal Consequences of the Construction of a Wall in the Occupied Palestinian Territory, Summary of Advisory Opinion (July 9 , 2004).

${ }^{19}$ Rep. of the High-level Panel on Threats, Challenges, and Change, UN Doc. A/59/565 (Dec. 2, 2004); GAOR, 59th Sess. (2004).

${ }^{20}$ UN Rep. of the Security Council, Security Council Working Methods: A Tale of Two Councils?, No. 1/2014 (Mar. 25, 2014).

${ }^{21}$ GA Res. 498(V) (Feb. 1, 1951).

22 GA Res. 998 (ES-I) (Nov. 4, 1956).

${ }^{23}$ GA Res. 1004 (ES-II) (Nov. 4, 1956). 
Union to withdraw all of its forces and requested the Secretary-General investigate the situation. Further, in 1958, the Assembly requested ${ }^{24}$ that the Secretary-General make practical arrangements to facilitate early withdrawal of foreign troops from Jordan and Lebanon. In the case of the situation in the Republic of Congo in 1960, the Assembly again affirmed ${ }^{25}$ the Council resolution authorizing the Secretary-General to take the necessary steps to provide the Congo Government with military assistance and appealed to all Congolese to seek a speedy solution to their internal conflicts. In 1967, after the Six-Day War in the Middle East, it considered that the measures taken by Israel to change the status of the City of Jerusalem were invalid ${ }^{26}$ and called upon Israel to rescind ${ }^{27}$ the measures already taken and desist from any other action. This action also considered the consequence of the breach of the peace and addressed the issues of international responsibility.

Moreover, in the 1971 conflict between India and Pakistan over East Pakistan (Bangladesh), the Assembly dealt with the question of international assistance ${ }^{28}$ to the refugees from East Pakistan in India. The Soviet invasion of Afghanistan in 1980 involved the Assembly's call for the withdrawal ${ }^{29}$ of foreign troops from Afghanistan and its appeal to all States and national and international organizations to extend humanitarian relief assistance. Starting in 1980, the Assembly also adopted several resolutions ${ }^{30}$ in the case of Palestine, calling for Israel to withdraw from all Palestinian and other Arab territories occupied since 1967, demanding compliance with prior Council resolutions, demanding the dismantling of settlements, condemning the violations of international humanitarian law, and calling for investigations. Resolution ES-7/231 also requested that the Council, in the event of Israel's non-compliance, consider the adoption of effective measures under Chapter VII of the Charter. That resolution also affirms the Council's central role in the maintenance of international peace and security.

Further, in 1981 with regard to the South African occupation of Namibia, the Assembly affirmed ${ }^{32}$ the Namibian people's right to self-determination and declared that the illegal occupation constituted a breach of international peace and security. In that instance the Assembly expressed its support for the South West Africa People's Organization as the sole and authentic representative of the Namibian people. It also called upon the international community to extend all support and assistance (including military assistance) to defend Namibia's sovereignty and territorial integrity and urged the Council and all States to impose sanctions on South Africa. The Council was further involved in the enforcement of the Assembly resolutions with regard to the eventual withdrawal of South Africa from Namibia.

In 1982, after the Israeli annexation of the Golan Heights, the Assembly considered ${ }^{33}$ Israel not to be a peace-loving UN Member State and declared that its actions in the occupied Syrian Golan Heights constituted an act of aggression and should not be recognized. It also asked for Israel's withdrawal from all Palestinian and other Arab territories occupied since 1967 and called upon UN Member States for non-assistance. In

${ }^{24}$ GA Res. 1237 (ES-III) (Aug. 21, 1958).

${ }^{25}$ GA Res. 1474 (ES-IV) (Sept. 20, 1960).

${ }^{26}$ GA Res. 2253 (ES-V) (July 4, 1967).

${ }^{27}$ GA Res. 2254 (ES-V) (July 14, 1967).

${ }^{28}$ GA Res. 2790 (XXVI) (Dec. 6, 1971).

${ }^{29}$ GA Res. ES-6/2 (Jan. 14, 1980).

${ }^{30}$ GA Res. ES-7/2 (July 29, 1980); GA Res. ES-7/3 (July 29, 1980); GA Res. ES-7/4 (Apr. 28, 1982); GA Res. ES-7/5 (June 26, 1982); GA Res. ES-7/6 (Aug. 19, 1982); GA Res. ES-7/7 (Aug. 19, 1982); GA Res. ES-7/8 (Aug. 19, 1982); GA Res. ES-7/9 (Sept. 24, 1982).

31 GA Res. ES-7/2 (July 29, 1980).

${ }^{32}$ GA Res. ES-8/2 (Sept. 14, 1981).

${ }^{33}$ GA Res. ES-9/2 (Feb. 5, 1982). 
1997, referring to prior resolutions affirming that the Israeli settlement policy in the Occupied Palestinian Territory was illegal and concerned about Israel's construction of a wall in the Occupied Palestinian Territory, the Assembly requested ${ }^{34}$ an advisory opinion from the International Court of Justice.

This Assembly practice in cases when the Council has been blocked from taking a decision affirms that in difficult cases involving the maintenance of peace and security the Assembly reacts to the (in)action of the Council and stipulates the consequences of the breach of the peace or the act of aggression. Some scholars ${ }^{35}$ have questioned the overall effectiveness of the Assembly in addressing threats to international peace and security. Of course, the role of seeking political consensus at the Assembly has its influence on the substance of determinations with regard to a particular conflict. At the same time, the specific role of the Assembly in reacting to international conflicts predetermines that the Council may not always follow up on the same legal and political grounds on which the Assembly resolutions have been adopted.

With regard to State responsibility, for example, the Council either affirms the well-established rules of State responsibility or attempts to indicate special rules on the basis of the Charter. This field of law is of particular interest for the purposes of discussing the Council's role, as it reflects the Assembly's efforts to spell out the consequences of breaches of the peace based on a State's wrongdoing. In the case of Ukraine, the Assembly adopted Resolution 68/262,36 whose preamble refers to binding international law. However, the operative part strongly confirmed existing State responsibility law: namely, the duty of states not to recognize the acquisition of territory accomplished through a serious breach of international law. ${ }^{37}$ This resolution also demonstrates the Assembly's capacity to recommend that States adopt certain measures as a consequence of threats to the international peace. In this and prior instances, the Assembly has assumed the power to stipulate that an internationally wrongful act has been committed by the responsible State, as it needs to make such an affirmation in order to establish the consequences. When the Assembly does this, it imposes on the Council the need to consider for its part whether to proceed to take enforcement action in the exercise of its respective powers over the maintenance of international peace and security. As the Assembly does not adopt binding determinations, it did not feel bound in that instance to react to the particular breach of an international obligation even though it recognized that, given the underlying facts, issues of international responsibility were implicated.

The practice of the Assembly shows that the Uniting for Peace resolution has been interpreted in a more restrictive fashion than its terms would suggest. The Resolution has tried to pave the way for expanding the Assembly's practice in the maintenance of international peace and security. However, in practice, the Assembly's activity has generally affirmed the need for Council involvement and for the Assembly to limit its role to indicating the consequences of the breach of the peace. The use of veto by a Council permanent member as a condition for resorting to the Uniting for Peace resolution will allegedly become questionable in cases, if the permanent members choose not to use the veto in cases of jus cogens and human rights violations. This aspect will affirm the Council's constant authority over issues of peace and security not only from the perspective of the division of tasks between the political organs, but from the perspective of the Council's international obligations as well.

\footnotetext{
${ }^{34}$ GA Res. ES-10/14 (Dec. 8, 2003).

35 The United Nations Security Council and War: The Evolution of Thought and Practice Since 1945 (Vaughan Lowe et al. eds., 2010).

${ }^{36}$ GA Res. 68/262 (Mar. 27, 2014).

${ }^{37}$ Int'l Law Comm'n, Responsibility of States for Internationally Wrongful Acts, 53rd Sess., Apr. 23-June 1, July 2-Aug. 10, 2001 , UN Doc. A/56/10; GAOR, 56th Sess. (2001).
} 